\title{
ДІЯЛЬНІСТЬ ПРАВООХОРОННИХ ОРГАНІВ ЩОДО ЗАБЕЗПЕЧЕННЯ ПРАВ І СВОБОД ЛЮДИНИ В НОРМАТИВНО-ПРАВОВОМУ ПОЛІ
}

\author{
ACTIVITIES OF LAW ENFORCEMENT AUTHORITIES TO ENSURE \\ THE RIGHTS AND FREEDOM OF THE HUMAN IN THE LEGAL AND LEGAL FIELD
}

\author{
Танько А.B., \\ кандидат юридичних наук, \\ докторант відділу організачії освітньо-наукової підготовки \\ Харківського національного університету внутрішніх справ
}

\begin{abstract}
У статті репрезентовано результати дослідження, що має на меті розкриття нормативно-правової основи забезпечення прав і свобод людини як підґрунтя діяльності правоохоронних органів України, висвітлення на цьому тлі ролі Національної поліції щодо забезпечення прав та свобод людини.

Наукова новизна дослідження полягає в тому, що на основі вивчення міжнародного та вітчизняного нормативного законодавства уточнено сутність провідних дефініцій, пов'язаних із забезпеченням прав і свобод людини: «права, свободи», «права людини і громадянина», «захищені ознаки», «інтерсекційність», «правоохоронні органи», диференційовано поняття «права» $\mathrm{i}$ «свободи», розкрито специфіку прав людини і громадянина, системно проаналізовано нормативно-правове підґрунтя соціально-правового захисту, визначено роль правоохоронних органів, зокрема Національної поліції України, у забезпеченні прав і свобод людини, накреслено шляхи підвищення ефективності діяльності правоохоронних органів щодо забезпечення соціальної стабільності в суспільстві.
\end{abstract}

Встановлено, що поглиблене розуміння сутності прав та свобод людини і громадянина забезпечує дотримання демократичного курсу розвитку держави, відбір таких форм і напрямів діяльності її правозахисних органів та інституцій, що забезпечують реалізацію принципу гарантування безпеки особи, який був закріплений у багатьох міжнародних документах, отримав свій подальший розвиток у нормах національного законодавства.

На основі вивчення конкретних нормативних положень розглянуто поняття «захищені ознаки» - характеристики людини, за якими в суспільстві не може бути привілеїв чи обмежень (раса, колір шкіри, політичні, релігійні та інші переконання, стать, етнічне та соціальне походження, майновий стан, місце проживання, мовні або інші ознаки), а також «інтесекційність» - сукупність або перетин зазначених ознак у контексті розгляду обставин життя конкретної людини. 3 огляду на це обґрунтовано сутність прав і свобод людини як загальний орієнтир держави та усіх її інституцій на рівність і справедливість розподілу суспільних благ і ресурсів.

Наголошено, що серед державних органів, на які покладено обов'язок здійснення заходів щодо забезпечення конституційних прав і свобод громадян, важливе місце відводиться Національній поліції, яка порівняно з іншими правоохоронними структурами вирішує найбільше коло питань, пов'язаних із забезпеченням прав і свобод людини. Визначено, що ця правозахисна структура, на відміну від інших, створена для безпосереднього контакту з громадянами, а тому якість надання правозахисних послуг державою може бути безпосередньо оцінена кожною людиною з власного життєвого досвіду. Відповідно, від якості та ефективності роботи Національної поліції залежить сприйняття громадськістю всіх інших видів діяльності правоохоронних органів.

На основі вивчення міжнародного та вітчизняного нормативного законодавства автором висвітлено соціально-правові категорії, пов'язані із забезпеченням прав і свобод людини; диференційовано поняття «права і свободи»; розкрито специфіку прав людини і громадянина; визначено роль правоохоронних органів, зокрема Національної поліції України в забезпеченні прав і свобод людини.

Ключові слова: права, свободи, захищені ознаки, інтерсекційність, права людини і громадянина, правоохоронні органи, діяльність Національної поліції України, міжнародне та вітчизняне законодавство.

The results of the study, aimed at revealing the legal framework for ensuring human rights and freedoms as a basis for the activity of law enforcement agencies of Ukraine, and highlighting the role of the National Police in ensuring human rights and freedoms, are presented.

The scientific novelty of the study is that, based on the study of international and national regulatory legislation, the essence of the leading definitions related to the protection of human rights and freedoms is specified: "rights, freedoms", "human and citizen's rights", "protected features", "intersectionality", "law enforcement agencies", differentiated the concept of "rights and freedom", revealed the specifics of human and citizen rights, systematically analyzed the legal basis of social and legal protection, defined the role of law enforcement agencies, of the National Police of Ukraine in the Protection of Human Rights and Freedoms, outlined ways to increase the effectiveness of law enforcement agencies in ensuring social stability in society.

It is established that an in-depth understanding of the essence of human and citizen's rights and freedoms ensures adherence to the democratic course of development of the state, selection of such forms and directions of activity of its human rights bodies and institutions, which ensure the implementation of the principle of guaranteeing the security of a person, which was enshrined in many international documents, received its further development of national legislation.

Based on the study of specific regulations, the concept of "protected features" - the characteristics of a person under which there can be no privileges or restrictions in the society (race, color, political, religious and other beliefs, gender, ethnic and social background, property status, place) residence, linguistic or other features), and intersectionality - the totality or intersection of these features in the context of considering the circumstances of a particular person's life. On this basis, the essence of human rights and freedoms as a general orientation of the state and all its institutions on the equality and fair distribution of public goods and resources is substantiated.

It is emphasized that among the state bodies, which are obliged to take measures to ensure the constitutional rights and freedoms of citizens, the National Police plays an important role, which, in comparison with other law enforcement agencies, addresses the most issues related to the protection of human rights and freedoms. It is determined that this human rights structure, unlike others, was created for direct contact with citizens, and therefore the quality of human rights services provided by the state can be directly assessed by each person from his or her own life experience. Accordingly, the public's perception of all other law enforcement activities depends on the quality and efficiency of the work of the National Police.

Key words: rights, freedoms, protected features, intersectionality, human and citizen rights, law enforcement agencies, activities of the National Police of Ukraine, international and national legislation.

Постановка проблеми. Сьогодні у зв'язку з обранням Україною шляху незалежності та інтеграцією іiі у Європейський простір на паритетних засадах проблема забезпечення й захисту прав і свобод людини та громадянина набула особливої гостроти в нормативно-правовому дискурсі. Розбудова правової держави визначає зміст і спрямо- ваність діяльності ії офіційних інституцій на засадах визнання людини найвищою цінністю, поваги до прав і свобод особистості, незалежно від наявності чи відсутності в неї ознак, що здатні знижувати ії статус у суспільстві.

Відповідно до 3-ї статті Конституції України забезпечення прав і свобод людини є головним обов'язком 
держави. Демократичні конституційні норми декларують вектор розвитку України як правової держави й грунтуються на визнанні міжнародних стандартів, де проголошено пріоритетність прав і свобод людини в суспільстві. Це й Загальна декларація прав людини, проголошена Генеральною Асамблеєю Організації Об’єднаних Націй $(\mathrm{OOH})$, прийнята Радою Європи Конвенція про захист прав людини й основоположних свобод й інші міжнародні документи. Важливим кроком у цьому напрямі $є$ прийняття Стратегії сталого розвитку «Україна - 2020», якою в Україні визначаються вектори руху щодо впровадження європейських стандартів життя в оборонній, соціальноекономічній, правоохоронній сферах [1].

Зорієнтувавшись на міжнародний курс щодо захисту прав і свобод усіх категорій населення, Україна взяла на себе зобов'язання щодо встановлення на своїй території демократичного і сенситивного до потреб людини правопорядку, що підтримується в державі, зокрема через функціонування системи спеціальних державних органів правоохоронних. Саме правоохоронні органи і покликані здійснювати захист прав і свобод людини і громадянина Наголосимо, що органи Національної поліції України посідають чільне місце серед таких державних інституцій. Відповідно до першої статті Закону України про Національну поліцію призначення цієї правозахисної структури полягає в служінні суспільству «шляхом забезпечення охорони прав і свобод людини, протидії злочинності, підтримання публічної безпеки і порядку» [2]. У своїй діяльності поліція керується Конституцією України, міжнародними договорами України, згода на обов'язковість яких надана Верховною Радою України, Законом України про Національну поліцію, актами Президента України та постановами Верховної Ради України, актами Міністерства внутрішніх справ України, іншими нормативноправовими актами.

Разом із цим деякі встановлені чинним законодавством поліцейські або запобіжні заходи за своєю сутністю передбачають втручання держави у права і свободи громадян, передбачені міжнародними документами. Це, зокрема, такі превентивні та кримінально-процесуальні запобіжні заходи, як обмеження пересування людини, домашній арешт та інші, що неминуче передбачають обмеження прав і свобод людини і водночас відповідають правовим нормам (стаття 2 Протоколу 7 Конвенції - право на свободу пересування) тощо. Такі винятки, за відсутності загального демократичного підходу й глибокого сприйняття прав і свобод людини як орієнтиру професійноі діяльності правоохоронних органів, можуть стати приводом для зловживань державною владою та суттєвих порушень прав і свобод людини, як було, наприклад, за роки існування Радянського Союзу.

У світлі зазначених ризиків і проблем особливого значення набуває поглиблення розуміння сутності прав і свобод людини в контексті діяльності правоохоронців, чітке виокремлення тих прав і свобод, що мають охоронятися або до яких може здійснюватися законне обмеження, а також формування сенситивного ставлення до визначення меж застосування поліцейських та інших процесуальних заходів, спрямованих на обмеження прав і свобод громадян.

Стан дослідження проблеми. Проблема забезпечення прав і свобод людини, зокрема у правоохоронній діяльності, за останнє десятиліття розглядалася багатьма дослідниками (В. Андрушко, В. Бабкін, О. Бандурка, О. Безпалова, В. Бесчасний, Ю. Бітяк, І. Бородін, С. Благовісний, В. Букач, А. Васильєв, В. Вознюк, К. Волинка, I. Гамалій, Д. Гараджасв, А. Головін, О. Горова, Т. Дашо, О. Домбровська, С. Ківалов, А. Колодій, А. Комзюк, Я. Кондратьєв, В. Кравченко, О. Негодченко, Н. Нижник, О. Онишко, М. Панов, В. Погорілко, П. Рабінович, О. Скакун, В. Тихий, М. Хавронюк, Ю. Шемшученко,
О. Фрицький та інші). Водночас, незважаючи на наявність досліджень у галузі правового захисту особистості, можна констатувати, що в контексті побудови демократичної, соціальної та правової держави, реформування соціальноправової системи України, проблема забезпечення прав і свобод людини стає особливо актуальною, залишаючись водночас не остаточно вичерпаною у сучасному нормативно-правовому дискурсі.

Мета і завдання дослідження. Метою статті є розкриття нормативно-правової основи забезпечення прав і свобод людини як підгрунтя діяльності правоохоронних органів України, висвітлення на цьому тлі ролі Національної поліції України щодо забезпечення прав та свобод людини.

Наукова новизна дослідження полягає в тому, що уточнено деякі базові поняття: «права, свободи», «права людини і громадянина», «захищені ознаки», «інтерсекційність», «правоохоронні органи»; системно проаналізовано нормативно-правове підгрунтя соціально-правового захисту, накреслено шляхи підвищення ефективності діяльності правоохоронних органів щодо забезпечення соціальної стабільності в суспільстві.

Виклад основного матеріалу. Ефективність діяльності правоохоронних органів значною мірою визначається правовим регулюванням усіх іiі аспектів й грунтується сьогодні на принципах гуманності та дотримання прав і свобод людини. Така гуманістична концепція діяльності правоохоронних органів в Україні поступово вироблялася в процесі затвердження міжнародних і вітчизняних нормативно-правових актів щодо захисту прав і свобод людини.

Проблема захисту прав і свобод людини набула статусу пріоритетної міжнародної проблеми після Другої світової війни, в процесі якої відбувалися численні порушення прав людини, масові приниження людської гідності, неприпустимі навіть в умовах військових подій дії стосовно цілих націй, переслідування та знищення державами категорій осіб, які вирізнялися дійсними або припущеними, іноді навіть помилково, ознаками (інвалідність, релігійні погляди, політичні переконання тощо). Відповідно, на світовому рівні назріла нагальна потреба в розробці дієвих універсальних механізмів міжнародного регулювання правових стандартів, побудованих на високих гуманістичних засадах сучасного цивілізаційного світу щодо дій держав по відношенню до громадян. Такими механізмами стали правові рекомендації визнаних у світі міжнародних організацій (Організація об'єднаних націй, Рада Європи) у сфері забезпечення прав і свобод людини, що поступово були ратифіковані державами світу, в тому числі й Україною, і встановили загальнолюдські стандарти етичних дій держави по відношенню до громадян.

Одними 3 перших такими документами стали: Загальна декларація прав людини, проголошена Генеральною Асамблеєю ООН 10 грудня 1948 року, яку Україна ратифікувала ще в 1973 році; Конвенція про захист прав людини і основоположних свобод, прийнята Радою Європи 4 листопада 1950 року та ратифікована Україною 17 липня 1997 року; Міжнародний пакт про громадянські та політичні права, затверджений міжнародною спільнотою в 1966 році та ратифікований Україною в 1969 році, затверджений і ратифікований у ті ж самі роки Міжнародний пакт про економічні, соціальні та культурні права. Ці міжнародні документи сьогодні залишаються найавторитетнішим джерелом міжнародних норм щодо прав і свобод людини.

Питанню декларування прав і свобод людини присвячені перші статті Загальної декларації прав людини, де проголошується, що всі люди народжуються вільними і рівними у своїй гідності та правах (ст. 1) і кожна людина має володіти усіма правами і усіма свободами, проголошеними цією Декларацією, без будь-яких відмінностей, 
як-то стосовно раси, кольору шкіри, статі, мови, релігії, політичних чи інших переконань, національності чи соціального походження, майнового чи будь-якого іншого стану (ст. 2) [3].

У контексті визначення основних нормативно-правових пріоритетів української держави у сфері захисту прав i свобод людини, а відповідно, і вибудовування правозахисних орієнтирів у галузі діяльності правоохоронних органів України, надважливим $є$ не лише проголошення загальної рівності всіх осіб без будь-яких винятків, а й виокремлення тих ознак, якими позначаються групи населення, права яких традиційно порушуються в суспільстві. Важливо наголосити, що подібні ознаки відбито й у Розділі II Конституції України, що саме й регламентує права, свободи та обов'язки людини і громадянина. Так, у статті 24 цього розділу зазначається, що в суспільстві не може бути привілеїв чи обмежень за ознаками раси, кольору шкіри, політичних, релігійних та інших переконань, статі, етнічного та соціального походження, майнового стану, місця проживання, за мовними або іншими ознаками [4]. Перелічені характеристики мають назву «захищені ознаки», а їх сукупність або перетин у контексті розгляду обставин життя конкретної людини, що піддається взаємопов'язаним формам домінування або дискримінації, називають інтесекційністю (множинна або перехресна дискримінація).

Слід наголосити, що конституційні права й свободи людини і громадянина відзначаються певними рисами та характеристиками, відрізняються від інших прав за змістом і формою закріплення, що виділяє їх із загальної системи прав людини і позначає вирішальну роль цих прав і свобод у встановленні правового статусу особи в суспільстві та державі. Це пов'язано з тим, що права і свободи людини набувають статусу конституційних лише після закріплення їх конституцією країни, за їх допомогою втілюються і регулюються суттєві соціальні відносини між державою і громадянами.

Виходячи із зазначеного вище, можна не лише 3'ясувати сутність прав і свобод людини як загального орієнтиру держави й усіх іiі інституцій на рівність і справедливість розподілу суспільних благ і ресурсів, а й отримати чіткий дороговказ щодо роботи правозахисних структур держави з тими категоріями осіб, які потребують особливої уваги. У зв'язку з цим О. Негодченко наголошує, що до провідних характеристик правового демократичного суспільства належить не тільки домінування в ньому волевиявлення більшості населення, а й визнання та захищеність, непорушність основних прав усіх осіб, включаючи й тих, що становлять його меншість. Тому держава реальних прав людини може існувати тільки в суспільстві, де панує справжня демократія, тобто повновладдя більшості 3 дотриманням прав меншості [5, с. 22].

У цьому контексті міжнародною спільнотою було затверджено низку законодавчих актів щодо захисту прав i свобод різних категорій осіб, яким притаманні перелічені вище захищені ознаки або їх сукупність (інтерсекційність). Стрижневими міжнародними документами щодо захисту категорій осіб, права і свободи яких традиційно порушувалися в суспільстві, $\epsilon$ зокрема: Конвенція про попередження злочину геноциду і покарання за нього від 1948 року, підписана Україною в 1949 році та ратифікована в 1954 році; Декларація ООН про ліквідацію всіх форм расової дискримінації, прийнята Генеральною Асамблеєю 21 грудня 1965 року, що набула чинності 4 січня 1969 року; Міжнародна конвенція про ліквідацію всіх форм расової дискримінації від 21 грудня 1965 року, що набула чинності в 1969 році й була ратифікована Україною 1969 року; Конвенція ООН про права дитини від 20 листопада 1989 року, ратифікована в Україні 27 лютого 1991 року; Конвенція ООН про ліквідацію всіх форм дискримінації щодо жінок, що вступила в силу 3 вересня 1981 року, ратифікована в Україні у 2003 році; Конвенція про права осіб з інвалідністю, підписана 13 грудня 2006 року і ратифікована в Україні 16 грудня 2009 року та багато інших міжнародних документів.

Зазначимо, посилаючись на твердження О. Онишко, що 3 моменту ратифікації державами міжнародно-правових актів, права людини стали об'єктом регулювання не лише окремої країни, а й міжнародної спільноти [6, с. 52]. Це означає, що перелічені вище міжнародні документи отримали верховенство над внутрішнім законодавством, що забезпечило людині можливість звертатися за захистом безпосередньо до міжнародного Комітету з прав людини при $\mathrm{OOH}$, у разі порушення її політичних і громадянських прав, коли можливості захисту, надані національним законодавством, були вичерпані.

Аналізуючи зміст зазначених міжнародних документів, необхідно наголосити, що без визнання пріоритетності прав і свобод людини в нормативному полі, суспільній свідомості та практиці діяльності силових структур держави неможливо побудувати дійсно демократичну правову державу. Дотримання державою прав і свобод людини, забезпечення їх у повному обсязі, без жодних винятків на засадах паритетності та рівнодоступності є важливим орієнтиром вітчизняної правозахисної системи. Не випадково увага вчених-юристів приділяється сьогодні питанням захисту прав і свобод людини.

Права людини в науковому контексті (I. Гамалій, В. Денисов, О. Негодченко, Т. Яблонська та інші) визначаються як можливості та вимоги вищого рівня, зумовлені фактом існування людини в суспільстві, пов'язані з рівнем розвитку цивілізації та детерміновані пріоритетністю потреб людини в соціумі. Дефініція «права людини» тісно пов'язана із розумінням сутності її свобод й іноді визначається через останнє поняття. Так, за твердженням В. Тертишника, права виступають мірою свободи, засобом забезпечення свободи й водночас істотним засобом обмеження неузгоджених із суспільними потребами і уявленнями людей про добро і справедливість рівня свободи й обсягу влади [7, с. 89]. Так, Т. Дашо наголошує, що права людини - це визначені нормативно структуровані властивості та особливості буття людини, які виражають iii свободу і $є$ невіддільними та необхідними способами й умовами іiї життя, її взаємовідносин із суспільством, державою, іншими індивідами. Разом із цим свобода визначається дослідником як відсутність державного свавілля 3 установленням легітимних, розумних та пропорційних обмежень держави в реалізації людиною своїх основних прав. Свободи людини належать їй назавжди, визначають iіi здатність до самостійних дій і не залежать від визнання державою. Отже, природні права (права людини) забезпечують сферу індивідуальної та суспільної свободи від деспотичного державного втручання [8, с. 110, 115].

Зважаючи на те, що згідно із статтею 6 Закону України «Про Національну поліцію» ця правозахисна структура у своїй діяльності керується принципом верховенства права, відповідно до якого людина, ії права та свободи визнаються найвищими цінностями та визначають зміст і спрямованість діяльності держави [2], необхідно розвести поняття «права» і «свободи». Тим більше, що вони суттєво розрізняються за способами реалізації й забезпечення: свободи зазвичай здійснюються без втручання певних засобів регулювання і пов'язані із життєвим вибором людини (свобода віросповідання, слова, місця проживання тощо), тоді як забезпечення прав переважно здійснюється державою та іiі інституціями (право на освіту, право на працю тощо). Одним із найважливіших принципів здійснення прав людини є вимога суспільно відповідального їх використання всіма і кожним, відповідно до здійснення людиною свого права може бути обмеженим правами іншої людини, яка також є рівною по значущості в умовах демократичної правової держави [6, с. 10]. 
Суттєвим також є те, що в науці та юридичній практиці розрізняють права людини і громадянина. Перші мають природну основу і $є$ невіддільними для всіх індивідів, $є$ позанаціональними, позатериторіальними, існують незалежно від закріплення в законодавчих актах держави, виступають об'єктом міжнародно-правового регулювання і захисту [5, с. 23-24]. Права людини - це певні можливості, необхідні для існування та розвитку людини в конкретно-історичних умовах, які об'єктивно визначаються досягнутим рівнем розвитку історії людства (духовного, соціального, економічного) і мають бути рівними для всіх людей [9, с. 17]. Відповідно, права людини тлумачаться як іiї природні права, притаманні їй від народження, що $\epsilon$ пріоритетними, оскільки поширюються на всіх людей незалежно від їх місця проживання чи перебування, тоді як права громадянина поширюються лише на громадян певної держави [6, с. 9-10]

Сьогодні держава бере на себе обов'язки щодо соціально-правового забезпечення прав і свобод людини через підтримання в конкретному суспільстві умов щодо їх peaлізації (заходи, що забезпечують дотримання прав і свобод людини), створення системи охорони (заходи з профілактики правопорушень задля утвердження правомірної поведінки особи) й захисту (заходи щодо відновлення прав, порушених неправомірними діями, і притягнення до відповідальності осіб, які вчиняють правопорушення).

Для забезпечення прав людини в державному механізмі кожної країни діє спеціальна система органів, які здійснюють правоохоронну діяльність. Згідно 3 Конституцією України до системи забезпечення прав і свобод людини і громадянина належать фактично всі ланки державної влади, починаючи з Верховної Ради і Президента України, у діяльності яких правове забезпечення є важливими, але не єдиним напрямом. Разом із цим існують установи й організації, тобто правоохоронні органи, спеціально створен у суспільстві для здійснення правозастосовної та правоохоронної функцій забезпечення законності, захисту прав 1 законних інтересів громадян, юридичних осіб, держави, боротьби зі злочинністю та іншими правопорушеннями шляхом застосування заходів юридичного примусу.

Серед таких державних органів, на які покладено обов'язок здійснення заходів щодо забезпечення конституційних прав і свобод громадян, важливе місце відводиться Національній поліції. Вона, порівняно з іншими правоохоронними структурами, вирішує найбільше питань, пов'язаних із забезпеченням прав i свобод людини. На цю структуру покладаються функції: захисту прав і свобод громадян від протиправних посягань, забезпечення громадської безпеки [10, с. 37]. На основ викладеного вище можемо стверджувати, що діяльність поліції зосереджена передусім на забезпеченні прав громадян держави та декларованих у державі свобод, хоча розуміння сутності та значення прав людини є підгрунтям для такої діяльності й орієнтування на них як на найвищу суспільну цінність.
Розглядаючи проблему захисту прав і свобод людини у контексті роботи поліції, слід наголосити, що ця правозахисна структура, на відміну від інших, постійно перебуває у фокусі пильної уваги громадян, від іiї якості й ефективності залежать практично всі інші види діяльності правоохоронних органів, й будь-яка особа на основі власного життєвого досвіду може сформувати думку щодо якості надання правозахисних послуг державою. Від цього врешті решт залежить ефективність забезпечення прав і свобод громадян у різних сферах життєдіяльності суспільства.

У діяльності поліції забороняються будь-які привілеї чи обмеження за ознаками раси, кольору шкіри, політичних, релігійних та інших переконань, статі, етнічного та соціального походження, майнового стану, місця проживання, за мовною або іншими ознаками [2].

Особливо гостро постає питання правового захисту людини і дотримання норм законності тоді, коли поліція вимушена здійснити заходи 3 обмеження прав і свобод людини, що допускається винятково на підставах та в порядку, визначених Конституцією і законами України, за нагальної необхідності та в обсязі, потрібному для виконання завдань поліції [2]. Підкреслимо, що такі дії мають тимчасовий характер і повинні бути негайно припинені, якщо мета їх застосування досягнута або в них немає подальшої необхідності.

Обмеження прав і свобод людини це зазвичай вимушена міра, до якої вдаються, щоб захистити законні права та інтереси іншої людини, які порушуються. Загалом же співробітникам поліції за будь-яких обставин заборонено сприяти, здійснювати, підбурювати або терпимо ставитися до будь-яких форм фізичного насилля, дискримінації, приниження гідності людини. У разі виявлення таких дій кожен поліцейський зобов'язаний негайно вжити всіх можливих заходів щодо їх припинення.

Висновки. 3 огляду на вищезазначене наголосимо, що поглиблене розуміння сутності прав і свобод людини й громадянина забезпечує дотримання демократичного курсу розвитку держави, відбір таких форм і напрямів діяльності іiі правозахисних органів та інституцій, які забезпечують реалізацію принципу гарантування безпеки особи, який був закріплений у багатьох міжнародних документах, отримав свій подальший розвиток у нормах національного законодавства.

Головне завдання правоохоронних органів полягає в забезпеченні законності, захисті прав і законних інтересів громадян, юридичних осіб, держави, боротьбі зі злочинністю, запобіганні правопорушенням.

На нашу думку, подальша детальна розробка й упровадження підходу до організації діяльності поліцейських структур, грунтованого на міжнародних правозахисних нормах, створюватиме сприятливі умови для формування в суб'єктів правозахисної діяльності цілісного уявлення про сутність і структуру прав і свобод людини, розуміння їхніх функцій у контексті сучасних правозахисних тенденцій.

\section{СПИСОК ВИКОРИСТАНИХ ДЖЕРЕЛ}

1. Безпалова О.І. Діяльність органів поліції щодо захисту прав людини під проведення операції Об'єднаних сил: Харківський національний університет внутрішніх справ: 25 років досвіду та погляд у майбутнє: Міжнародна науково-практична конференція (Харків, 22 лист. 2019 р.) / МВС України, Харків. нац. ун-т внутр. справ. Харків, 2019. С. 56-59.

2. Про Національну поліцію: Закон України від 02.07.2015 № 580-VIII. URL: https://zakon.rada.gov.ua/laws/show/580-19.

3. Загальна декларація прав людини від 10.12.1948. URL: https://zakon.rada.gov.ua/laws/show/995 015.

4. Конституція України від 28.06.1996 № 254к/96-ВР. Відомості Верховної Ради України. 1996. № 30. Ст. 141.

5. Негодченко О.В. Організаційно-правові засади діяльності органів внутрішніх справ щодо забезпечення прав і свобод людини : монографія. Дніпропетровськ : Вид-во Дніпропетр.ун-ту, 2003. 448 с.

6. Онишко О.Б. Забезпечення прав людини в правоохоронній діяльності : курс лекцій. Львів : Львівський державний університет внутрішніх справ, 2013. 256 с.

7. Тертишник В.М. Верховенство права та забезпечення встановлення істини в кримінальному процесі України : монографія. Дніпропетровськ : Дніп-роп. держ. ун-т внутр. Справ ; Ліра ЛТД, 2009. 404 с.

8. Дашо Т.Ю. Захист прав і свобод людини та громадянина на етапі формування громадянського суспільства. Вісник Національного університету «Львівська політехніка». Юридичні науки. 2015. № 813. С. 108-118.

9. Рабінович П.М. Проблеми юридичного забезпечення прав людини (загальнотеоретичний аспект). Український часопис прав людини. 1995. № 2. С. 16-23.

10. Криштанович М. Діяльність ОВС щодо захисту прав і свобод людини як важлива умова забезпечення національної безпеки України. Науковий вісник. 2013. Вип. 12 «Демократичне врядування». С. 34-38. 